\title{
Neonatal Screening for Lubumbashi Drepacytosis: Feasibility and Suitable Performance
}

\author{
Tina Katamea1, Criss Koba Mjumbe ${ }^{2 *}$, Maguy Ngongo Omoy', Dieudonné Bafwafwa1, \\ Matthieu Ngombe1, Lydie Kasongo', Gautier Mutoba1, Dieudonné Ngwej Tshikwej', \\ Amir Assumani N'Simbo1, Oscar Luboya Numbi', Léon Tshilolo3, Sanislas Wembonyama ${ }^{1,2}$
}

\footnotetext{
${ }^{1}$ Department of Pediatrics, Faculty of Medicine, University of Lubumbashi, Lubumbashi, The Democratic Republic of the Congo ${ }^{2}$ Department of Public Health, Faculty of Medicine, University of Lubumbashi, Lubumbashi, The Democratic Republic of the Congo ${ }^{3}$ Department of Pediatrics, “CEFA” Training and Health Support Center, Pediatric Hematology Service, Monkole Hospital Center, Kinshasa, The Democratic Republic of the Congo
}

Email: ${ }^{*}$ cryss_koba25@yahoo.fr

How to cite this paper: Katamea, T., Koba Mjumbe, C., Ngongo Omoy, M., Bafwafwa, D., Ngombe, M., Kasongo, L., Mutoba, G., Ngwej Tshikwej, D., Assumani N'Simbo, A., Luboya Numbi, O., Tshilolo, L. and Wembonyama, S. (2020) Neonatal Screening for Lubumbashi Drepacytosis: Feasibility and Suitable Performance. Open Access Library Journal, 7: e6121.

https://doi.org/10.4236/oalib.1106121

Received: January 30, 2020

Accepted: March 8, 2020

Published: March 11, 2020

Copyright $\odot 2020$ by author(s) and Open Access Library Inc.

This work is licensed under the Creative Commons Attribution International License (CC BY 4.0).

http://creativecommons.org/licenses/by/4.0/ (c) (i) Open Access

\begin{abstract}
Sickle cell anemia is a blood disorder linked to an abnormality in the structure of hemoglobin. The objective of this study was to determine the frequency of the sickle cell gene on the basis of early detection of hemoglobin using the isoelectric focusing technique in maternities in Lubumbashi. Our descriptive cross-sectional study consisted of newborns and infants up to 6 months of age. The capillary venous blood was collected on the finger for the rapid and direct test and on blotting paper for the electrophoresis of the hemoglobin of a few drops and the hemoglobin typing techniques performed by the isoelectric focusing technique. Statistical analyses were done using $\mathrm{R}$ version 2.0 software. We recruited 165 children, including ( 79 boys and 86 girls) who were at most 6 months old and all in good condition (100\%). For demographic characteristics, there was no statistically significant difference between males and females. We received almost all the tribes of the DRC in our study; the Luba of Katanga and those of Kasai were on the fringes and represented respectively (32.1\% and 29.1\%). (20.6\%) newborns with RDT and electrophoresis had an abnormality of hemoglobin in the homozygous or heterozygous state with (10.9\% SS; 9.7\% AS; and 0.6\%). Despite the large proportion in the group of children without tare after TRD and electrophoresis, our study did not show statistically significant differences. There is a significant correlation between the electrophoresis of hemoglobin between sex and age (coefficients of correlation $\mathrm{r}=0.99 ; \mathrm{p}<0.01$ ). When electrophoresis was compared in age group by category and sex, no statistically significant differ-
\end{abstract}


ence was noted. In Africa where family incomes are limited, it becomes necessary to develop a screening approach at a cost relatively accessible to all. Thus our study which does not claim to be exhaustive, makes a sketch in the experimentation of neonatal screening in the City of Lubumbashi.

\section{Subject Areas}

Cell Biology

\section{Keywords}

Screening, Neonatal, Drepacytosis, Lubumbashi, Haut Katanga, DR Congo

\section{Introduction}

Sickle cell anemia, also called sickle cell anemia, is a blood disorder linked to an abnormality in the structure of hemoglobin [1] [2]. It is due to the production of abnormal hemoglobin, linked to a mutation in the gene encoding the synthesis of the $\beta$-globin 3 chain, and transmitted by both father and mother (autosomal recessive transmission). This characteristic leads to the production of abnormal hemoglobin $\mathrm{S}(\mathrm{HbS})$, which causes deformation of red blood cells and disorders causing blockage of the vessels [3]. The distribution of the gene for this disease has been well characterized for several years: it is the most common genetic disease in the world since the sickle cell gene is found in more than 50 million people, with higher frequencies in Africa. Its highest frequencies generally coincide with areas of high malaria prevalence or having experienced a history of malaria [3] [4]. We attend the birth of more than 300,000 children each year with major sickle cell syndrome (MDS).

In Africa its prevalence varies between $10 \%-40 \%$ according to the regions and the ethnic groups. In the DRC, the ethnico-geographic distribution of the sickle cell trait varies between $6 \%-29 \%$ [5]. Clinically, subjects heterozygous for the disease do not express themselves or express themselves little. On the other hand, subjects with the double sickle cell gene (sickle cell homozygous SS) or associated with another hemoglobinopathy suffer from complications of the disease [5]. Depending on the genotype, genetic and environmental factors, the onset of these complications is in the vast majority of cases, between a few months and 5 years after birth, which is why sickle cell disease appears as a pediatric disease. The pathophysiology of complications is fairly well known; it essentially involves the sickling of the red blood cell which is the consequence of a gelling of $\mathrm{HbS}$ in a situation of tissue hypoxia, and increased adhesion of sickle cells to the wall of the vessels and therefore, phenomena of vascular obstruction [6] [7] [8]. Thus the natural clinical course of sickle cell anemia in these subjects who express themselves is schematically characterized by four evolutionary periods [9] [10]: the silent neonatal period; the period from 6 months to 5 years characterized mainly by serious infectious complications; the period of 5 to 15 
years marked, especially by the frequent occurrence of painful osteoarticular crises; the period of 15 years and beyond which is more characterized by anemic complications, but still infectious [11] [12]. Gene therapy opens up a prospect and offers hope for the cure of sickle cell disease [13] [14] [15]. If successful experiences of this therapy have been reported in animals [16] [17], it is not yet part of the proven therapeutic arsenal in humans; its mastery and the transfer of its technology to Africa will require several more years because the acquisition of the skills necessary for its practice, the establishment of health structures appropriate to this practice in the African context, require a lot of time. In the absence of these curative means, the experiences of neonatal diagnosis supported by regular medical monitoring [18], have sufficiently convinced the specialists and experts of sickle cell anemia, to consider that the strategy of early monitoring of sickle cell anemia after a diagnosis at birth is currently the best guarantor of the improvement of survival and comfort of the latter in Africa where $75 \%$ of sickle cell patients registered in the world live. The need to consider sickle cell anemia as a priority health problem in Africa, was stressed during several meetings bringing together specialists and associations in the fight against sickle cell anemia. Since 2006, sickle cell disease has thus been recognized as a public health priority worldwide. It should be noted that WHO had listed sickle cell disease in 1989 as one of the priority non-communicable diseases [19]. However, the need for considerable time for the acquisition of the skills necessary for the development of effective sickle cell disease control and case management programs, sufficiently justifies the urgency of feasibility studies for early diagnosis, in particular neonatal sickle cell disease and the follow-up of cases in Africa [4] [20]. The aim of our study was to determine the frequency of the sickle cell gene on the basis of early detection of hemoglobin using the isoelectric focusing technique in maternity wards at different hospitals in Lubumbashi.

\section{Methodology}

\subsection{Study Location}

Our study took place in the maternity hospitals of the various reference hospitals and health zones (Kenya, Kamalondo, University Clinics, Sendwe, Saint Jospeh golf) in Haut-Katanga/DR Congo.

\subsection{Study Type and Period}

This was a cross-sectional descriptive study which took place over three months in the various maternity hospitals and during prenatal consultations. Monitoring of study participants was active and passive. Active follow-up consisted of seeing the children again for a clinical examination and a para-clinical assessment. Families of study participants were asked to come to the pediatrician of the research team for any episode of illness; this component constituting a passive monitoring strategy, made it possible to record all the pathologies that occurred during the child's monitoring. 


\subsection{Study Population}

Our study population consisted of newborns and infants up to 6 months of age.

\subsection{Sample Size of Study Participants}

Recruitment focused on newborns seen at birth and infants. The follow-up of sick children made it possible to identify the problems linked to the regular follow-up of sickle cell anemia in Lubumbashi on the basis of the experience acquired during our follow-up period.

\subsection{Criteria for Inclusion in the Study}

Any child up to 6 months of age for whom mothers have signed for informed consent.

\subsection{The Procedure for Recruiting Volunteers}

Recruitment of volunteers took place in maternity hospitals and vaccination services. The written consent was administered by two physicians and/or the pediatrician responsible for the consultation after initial training in the procedure for administering consent.

\subsection{Blood Collection}

The venous capillary blood on the finger was collected for the rapid and direct test and on blotting paper for the electrophoresis of hemoglobin 1/2 drops. No sick children were taken into account. Blood samples for diagnostic purposes from sickle cell children during episodes of possible disease during follow-up were taken from a peripheral vein. Neonatal screening for sickle cell anemia in the Neonatology units of Lubumbashi.

\subsection{Hemoglobin Typing Techniques}

The hemoglobin typing was done by the isoelectric focusing technique supplemented possibly by the HPLC technique from the blood collected on blotting paper. This typing was conducted at the CUL Laboratory.

\subsection{Principle}

It consists in separating the different hemoglobin fractions by migrating a hemolysate on a plate of agarose gel containing RESOLVE ampholytes of pH: 6 - 8 . The different hemoglobins migrate more or less quickly depending on their isoelectric mobility, their molecular weight and their electrical charge.

\subsection{Hemolysate Preparation}

The preparation of the hemolysate depends on the type of sample (confetti or whole blood/cord blood). Newborn screening for sickle cell anemia in the neonatology unit. 


\subsection{Statistical Analyses}

Statistical analyzes were done using $\mathrm{R}$ version 2.0 software. For the comparison tests of means and frequencies, a value of $p \leq 0.05$ was considered significant.

\subsection{Ethical Considerations}

Consent was obtained from the guardian of each baby after being informed about the progress of the study. The study was approved by the medical ethics committee of the University of Lubumbashi

\section{Results}

\subsection{Socio-Demographic Characteristics of Children}

We recruited 165 (79 boys and 86 girls) whose ages varied between 0 months and 6 months, all initially were in good condition (100\%). For all demographic characteristics, there was no statistically significant difference between males and females.

\subsection{Age of children in Months}

The extremes of our children's ages were 0 to 6 months. With the median age being 3 months, $75 \%$ of the children were 1 to 4 months old.

\subsection{Tribe of Parents of Children}

We had to record the large part of the tribes of the DRC, in both sexes, the luba of Katanga and those of Kasaï were predominant and represented respectively (32.1\% and $29.1 \%)$ for the male sex and (39.4\% and $28.5 \%)$ for the female sex.

\subsection{Electrophoretic Profile of Parents}

In our series (Table 1(a)), the blood profile of the parents at the electrophoresis in the father group in (2.4\%) had an abnormality of hemoglobin in the homozygous or heterozygous state and (3.01\%) in mothers. The profile of their blood groupings were respectively for men and women $(\mathrm{A}+12.7 \%$; $\mathrm{AB}+5.5 \%$; $\mathrm{AS}$ $0.6 \% ; B+3.6 \%)$ and $(A+12.7 \% ; A B+5,5 \%$; AS 0.6\%; B + 3.6\%). It should also be noted that more than half of the parents, whatever the male or female gender, did not know the blood group (53.9\% for men and $42.4 \%$ women). At RDT and hemoglobin electrophoresis $21.2 \%$ of newborns had an abnormality of hemoglobin in the homozygous or heterozygous state with $10.9 \%$ SS; $9.7 \%$ of AS; and $0.6 \%$ of AC (Table $1(\mathrm{~b})$ ).

Despite the large proportion of hemoglobin abnormality in the homozygous or heterozygous state after TRD and electrophoresis, our study did not show statistically significant differences between children with tare and non-tare.

\subsection{Profile of RDT and Gender}

When the RDT was compared with sex (male and female), no statistically significant difference was noted (Table 2). But when we compare the RDT without 
Table 1. Blood profile of the study. (a) Electrophoretic profile of parents; (b) Blood profile of children.

(a)

\begin{tabular}{cccc}
\hline Variables & Grouping & Effective & Percentage \\
\hline Electrophoresis father & AA & 7 & 4.2 \\
& AS & 4 & 2.4 \\
Electrophoresis mother & unknown & 153 & 92.7 \\
& AA & 5 & 3.0 \\
& AS & 4 & 2.4 \\
Father Sanguin group & unknown & 154 & 93.3 \\
& SS & 1 & 0.6 \\
& A+ & 21 & 12.7 \\
& AB+ & 9 & 5.5 \\
& AS & 1 & 0.6 \\
& B+ & 6 & 3.6 \\
Oother Sanguin group & On & 36 & 21.8 \\
& A+ & 89 & 53.9 \\
& AB+ & 29 & 17.6 \\
& AS & 3 & 1.8 \\
& B+ & 1 & 0.6 \\
& O+ & 16 & 9.7 \\
& O- & 36 & 21.8 \\
& unknown & 1 & 0.6 \\
& & 70 & 42.4 \\
\hline
\end{tabular}

(b)

\begin{tabular}{cccc}
\hline Variables & Grouping & Effective & Percentage \\
\hline TDR & AA & 131 & 79.4 \\
& AC & 1 & 0.6 \\
& AS & 15 & 9.1 \\
Electrophoresis Result & SS & 18 & 10.9 \\
& AA & 131 & 79.4 \\
& AC & 1 & 0.6 \\
& AS & 15 & 9.1 \\
& SS & 18 & 10.9
\end{tabular}

Table 2. Profile of TDR and electrophoresis.

\begin{tabular}{cccc}
\hline \multirow{2}{*}{ Variables } & blood & parameters & Statistics \\
\cline { 2 - 3 } & Normal & Anormal & \\
\hline TDR (IIQ) & $131(79.4 \%)$ & $34(20.6 \%)$ & $\mathbf{Z}=\mathbf{0 . 5} ; \mathbf{p}=\mathbf{0 . 0 0 1}$ \\
Electrophoresis Result (IIQ) & $131(79.4 \%)$ & $34(20.6 \%)$ & $\mathbf{Z}=\mathbf{1} ; \mathbf{p}=\mathbf{0 . 0 8}$ \\
& Male & Women & \\
Tribe (IIQ) & $53(32.1 \%)$ & $48(29.1 \%)$ & $\mathbf{Z}=\mathbf{0 . 3} ; \mathbf{p}=\mathbf{0 . 2 1}$ \\
Sex (IIQ) & $79(47.9 \%)$ & $86(52.1 \%)$ & $\mathbf{Z}=\mathbf{0 . 3} ; \mathbf{p}=\mathbf{0 . 0 1}$ \\
\hline
\end{tabular}

*IIQ: Intrequartile interval, Z: Wilconxon statistical test, p: Statistical significance value. 
abnormality of child carriers (AS, AC and SS) we have a statistically significant difference $\mathrm{p}=0.0016$ (Table 2).

\subsection{Correlation of Age in Months and Gender}

The extremes of age for our children were from 0 to 6 months. When looking for a correlation by comparing the age and sex of child carriers with respect to RDT and hemoglobin electrophoresis (Figure 1). There is a significant correlation of hemoglobin electrophoresis between sex and age (correlation coefficient $\mathrm{z}=$ $0.99 ; \mathrm{p}<0.01)$.

\subsection{Association of Electrophoresis and Tribe of Parents}

The comparisons of the electrophoretic values of hemoglobin made between the population of our study to their tribe, did not show a statistically significant difference for the set of parameters concerned by the study of group AA, AC, AS and SS (Table 2).

\subsection{Association of Age, Sex and Electrophoresis}

When the electrophoresis was compared in the age group by category and sex, no statistically significant difference was noted.

\section{Discussion}

The size of our study was 165 newborns. Recruitment was made in the neonatal departments of Lubumbashi and the biology laboratory of the University Clinics of Lubumbashi (CUL) served as a place for processing the samples. Although the delivery of the blotting papers in an envelope to the CUL laboratory proceeded without major difficulty, the ideal would have been to carry out the tests on site. Unfortunately, there is no laboratory currently practicing isoelectrofocusing for hemoglobin in Lubumbashi, the primary neonatal diagnostic method for sickle cell anemia. Among the samples taken from newborns, only very few could be

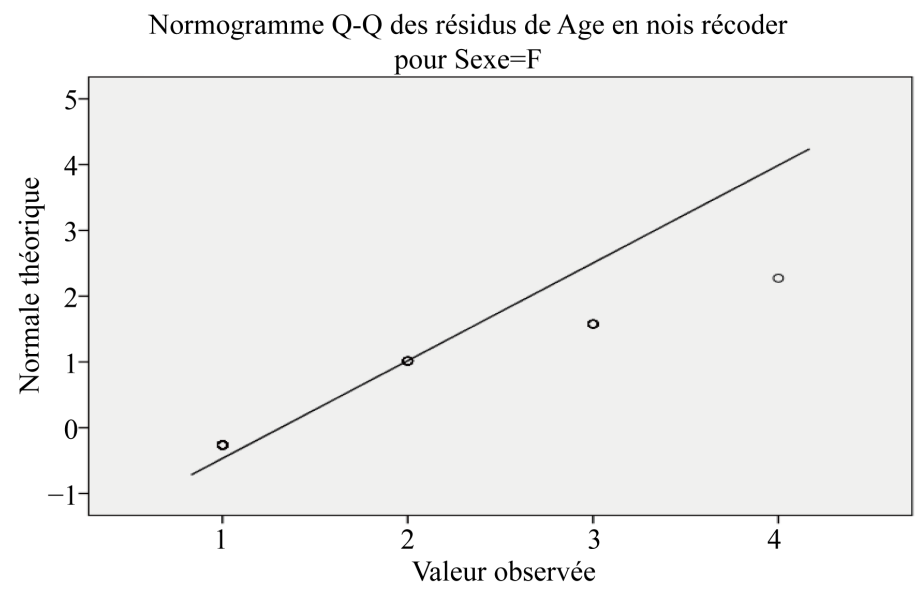

Figure 1. Correlation figure between sex and age in relation to hemoglobin electrophoresis. 
analyzed due to the insufficient blood drop on blotting paper. This was due to a lack of mastery of sampling techniques at the start of the study. Electrical isofocusing is a diagnostic technique of choice used for the detection of hemoglobinopathies in newborns. This is the technique used in the majority of neonatal screening programs, neonatal screening for sickle cell anemia is not yet a routine practice in our environment with the application of High Performance Liquid Chromatography (HPLC) being less used while these two techniques have excellent sensitivity and specificity [21] [22]. The majority of the parents were Luba from Katanga followed by luba from Kasai, contrary to what was thought to be observed in daily practice. This may be due to the geographic location and accessibility in which the study was carried out and the distance between Katanga and Kasai which could explain this percentage in its attendance. The ethnic distribution of mothers and that of fathers in all ethnic groups approximated with a predominance respectively of the Luba of Katanga, followed by the Luba of Kasai. This ethnic distribution of the parents had the same tendency in the two other studies carried out on multiple and eutocic pregnancies in Lubumbashi. Note that our study is not specifically concerned with a given ethnic group or origin.

Frequency of sickle cell phenotypes and major sickle cell syndromes at birth In our study $21.2 \%$ of newborns had an abnormality of hemoglobin in the homozygous or heterozygous state with $10.9 \%$ SS; $9.7 \%$ of AS; and $0.6 \%$ of AC. This result is similar to that reported in 1997 by Mbodj M., Ndoye O., et al. in Dakar [23] [24] on a smaller but significant sample of Dakar newborns; or 11.1\% of hemoglobinopathies with $7.9 \%$ of the trait Neonatal screening for sickle cell anemia in two gynecology departments with large affluence in Bamako (CHU.Point-G) sickle cell anemia (AS); $1.9 \%$ homozygotes (SS) and $0.2 \%$ carriers of SC heterozygosity. In Nigeria Odunvbun et al. reported 133 (20.6\%) of 644 newborns with the AS sickle cell trait, 7 (1.1\%) with the AC trait and 3\% of major sickle cell syndromes [25]. On the other hand, Tshilolo et al reported in a study carried out with 31,204 newborns in the DRC a prevalence of $1.4 \%$ of SS homozygous sickle cell anemia and $16.9 \%$ of carriers of the AS sickle cell trait [26]. Kafando E. et al. had reported in Ouagadougou in Burkina Faso, a prevalence of $25.55 \%$ of hemoglobinopathies with $1.75 \%$ of newborns carrying a major sickle cell syndrome and $18.2 \%$ of carriers of hemoglobin C in the state homozygous or heterozygous [27] [28] [29]. According to the WHO report in December 2005 on sickle cell disease, the prevalence of the sickle cell gene at birth is estimated at $24 \%$ in Nigeria, with $0.02 \%$ of newborns carrying a major sickle cell syndrome [30] [31] on the other hand, in Burundi Moreno JL and Baribwira C. had reported a prevalence of $0.42 \%$ of major sickle cell syndromes in newborns [32]. In Uganda Serjeant G. R. and Ndugwa C. M. had found a prevalence of $20 \%$ of carriers of the sickle cell trait [33] while in Zaire Tshilolo L., Mukendi R., and Girot R. had found a prevalence of 60\% [34]. A study carried out in 2005 in Bamako (Mali) found $9.9 \%$ of carriers of the sickle cell trait and $0.8 \%$ of major 
sickle cell syndromes [22] the same year found $8.5 \%$ of carriers of sickle cell disease and $0.5 \%$ of major sickle cell syndromes in Dakar (Senegal) these results are comparable to that of our study. It is known that the sickle cell gene is more common in the countries of Central Africa than in those of West Africa. Newborn screening for sickle cell disease in two busy gynecology departments in Bamako (CS Ref V and CHU.Point-G) In the United States, Grover et al. out of 106,565 newborns found 141 newborns with MDS, i.e. prevalence of $0.13 \%$ [35]. Gulbis B. et al. found $0.04 \%$ of MDS in Brussels with 1.5\% of hemoglobinopathy carriers [36] [37]. In Great Britain, the prevalence of hemoglobinopathies at birth is $6.9 \%$. Meaning of our results the results of this study obtained at the end of a new approach which consisted in seeing the feasibility and the performance of studying both the hemoglobin of newborns at birth and that of their mothers, confirms the data observed in the newborn in Lubumbashi in 2019. Sickle cell anemia is therefore a major health problem in DR Congo. If in the 1970s, the life expectancy of sickle cell disease was less than 10 years, we have known since the 2000s that this life expectancy has exceeded 45 years in countries that have successfully implemented a policy of neonatal screening of the disease, supported by early medical management of sickle cell patients screened from birth [36]. To improve the prognosis of sickle cell anemia in DR Congo, it is therefore important to set up an early detection of sickle cell children. Our results raise the crucial question of a systematic or targeted screening program for sickle cell anemia in the DRC. The two major sickle cell syndromes encountered in the study newborns were, in fact, the SS $(0.28 \%)$ and SC $(0.40 \%)$ phenotypes. The most reliable way to characterize these phenotypes at birth is currently isoelectrofocusing, sometimes supplemented by HPLC. These examinations are expensive and raise the question of their efficiency in a systematic approach for a low-income population. A targeted approach involves studying the hemoglobin profile of mothers before giving birth, which would make it possible to decide whether or not to screen newborns. This approach is possible thanks to less expensive techniques than isoelectrofocusing. The advantage of targeting based on cheaper and consistently positive test results in this category of mothers, such as the Itano test and the Emmel test, which are very accessible to laboratories, can therefore be discussed. These tests which are certainly less expensive and more accessible, however, do not make it possible to detect mothers who have a hemoglobin phenotype AC or CC and who, by the games of genetic combinations, can give birth to children suffering from MDS and therefore delay recognition of these children. It is therefore important to continue this study with additional cost/effectiveness studies, to find the most efficient approach to early detection of sickle cell disease in the DRC.

\section{Conclusion}

The prevalence of sickle cell anemia observed during this non-targeted screening using the combination of isoelectrofocusing and HPLC techniques poses the 
problem of its accessibility to a large majority of the population. In developed countries, considerable progress has been made in the management of sickle cell anemia through early detection. In Africa, where family incomes are limited, it becomes necessary to develop a screening approach at a cost relatively accessible to all. Thus our study, which does not claim to be exhaustive, makes a sketch in the experimentation of neonatal screening in the City of Lubumbashi. In addition, the possibility of sickle cell births in pregnant women who do not carry the $S$ gene deserves special attention.

\section{Recommendations}

Encourage voluntary screening for sickle cell disease, particularly in young people, and have the habit of referring major sickle cell syndromes to the specialized center.

\section{Conflicts of Interest}

The authors declare no conflicts of interest regarding the publication of this paper.

\section{References}

[1] Ingram, V.M. (1956) A Specific Chemical Difference between the Globins of Normal Human and Sicklecell Anaemia. Nature, 178, 792-794. https://doi.org/10.1038/178792a0

[2] Marotta, C.A., Wilson, J.T., Forget, B.J. and Weissman, S.M. (1977) Human $\beta$-Globin Messenger RNA III. Nucleotide Sequences Derived from Complementary DNA. The Journal of Biological Chemistry, 252, 5040-5051.

[3] Flint, J., Harding, R.M., Boyce, A.J. and Clegg, J.B. (1998) The population genetics of the haemoglobinopathies. In: Higgs, D.R. and Weatherhall, D.J., Eds., Bailliere's Clinical Haematology. Haemoglobinopathies, Bailliere Tindall WB Saunders, London, England, 1-51. https://doi.org/10.1016/S0950-3536(98)80069-3

[4] Weatherall, D.J. and Clegg, J.B. (2001) Inherited Haemoglobin Disorders: An Increasing Global Health Problem. Bulletin of WHO, 70, 704-712.

[5] Serjeant, G.R. and Serjeant, B.E. (2001) Sickle Cell Disease. 3rd Edition, Oxford University Press New York. https://doi.org/10.1046/j.1365-2141.2001.02557.x

[6] Elion, J. and Labie, D. (1996) Physiological Molecular and Cellular Bases for the Treatment of Sickle Cell Anemia. Hematology, 2, 499-510.

[7] Elion, J. and Labie, D. (1998) Sickle Cell Anemia and Cell Adhesion. Hematology, 4, 201-211.

[8] Rosse, W.F., Narla, M., Petz, L.D. and Steinberg, M.H. (2000) New Views of Sickle Cell Disease Pathophysiology and Treatment. Hematology (American Society of Hematology Education Program Book), 2-17. https://doi.org/10.1182/asheducation.V2000.1.2.2

[9] Powers, D.R. (1975) Natural History of Sickle Cell Disease. The First Ten Years. Seminars in Hematology, 12, 267-285.

[10] Hoppe, C., Styles, L. and Vichinsky, E. (1998) The Natural History of Sickle Cell Disease. Current Opinion in Pediatrics, 10, 49-51. https://doi.org/10.1097/00008480-199802000-00010 
[11] Galactéros, F. (2001) Physiopathology Basis of Sickle Cell Disease, Management and Current Therapeutics. Bulletin de la Société de Pathologie Exotique, 94, 77-79.

[12] Rochant, H., Bernaudin, F., Cornu, G., Davies, S., Fondu, P., Galacteros, F. and Girot, R. (1996) The Role of Bone Marrow Transplantation in the Treatment of Sickle Cell Anemia. Hematology, 2, 334-343.

[13] Sergeant, G. (2001) The Emerging Understandings of Sickle Cell Disease. Journal of Hematology, 112, 3-18. https://doi.org/10.1046/j.1365-2141.2001.02557.x

[14] Walters, M.C., Storb, R., Patience, M., Leisenring, W., Taylor, T., Sanders, J.E., et al. (2000) Impact of Marrow Transplantation of Symptomatic Sickle Cell Disease, an Interim Report. Blood, 95, 1918-1924.

[15] Pawliuk, R., Westerman, K.A., Fabry, M.E., et al. (2001) Correction of Sickle Cell Disease in Transgenic Mouse Models by Gene Therapy. Science, 294, 2368-2371. https://doi.org/10.1126/science.1065806

[16] Rivella, S. and Sadelain, M. (2002) Therapic Globin Gene Delivery Using Lentiviral Vectors. Current Opinion in Molecular Therapeutics, 4, 505-514.

[17] Weatherall, D.J. (2003) Genomics and Global Health: Time for a Reappraisal. Science, 302, 597-598. https://doi.org/10.1126/science.1089864

[18] Serjeant, G.R. and Serjeant, B.E. (1993) Management of Sickle Cell Disease; Lessons from the Jamaican Cohort Study. Blood, 7, 137-145. https://doi.org/10.1016/0268-960X(93)90001-K

[19] World Health Organization (1994) Guidelines for the Control of Hemoglobin Disorders. World Health Organization Publications, Geneva.

[20] Diallo, D.A. (2008) Sickle Cell Anemia in Africa: Issues, Strategies for Improving the Survival and Quality of Life of Sickle Cell Anemia. Bulletin de L'Académie Nationale de Médecine, 192, 1361-1373. https://doi.org/10.1016/S0001-4079(19)32686-X

[21] Health Planning Unit of the Ministry of Health \& National Statistics Department (2002) Mali III Demographic and Health Survey 200 (EDS MIII) 200. Report.

[22] Diallo, D. (2005) Feasibility of Neonatal Screening for Sickle Cell Anemia in Bamako.

[23] E.D.S. Mali Demographic and Health Survey-2003.

[24] Galacteros, F. (1996) Neonatal Detection of Sickle Cell Anemia in Metropolitan France. Archives de Pédiatrie, 3, 1026-1031. https://doi.org/10.1016/0929-693X(96)81727-1

[25] Rahimy, M.C. (1999) Early Detection and Medical Management of Sickle Cell Disease: Five Years of Experience in Cotonou. Archives de Pédiatrie, 6, 343-344. https://doi.org/10.1016/S0929-693X(99)80462-X

[26] Kete, C.V. (1998) Newborn Screening for Sickle Cell Anemia Using the Hemoglobin Isoelectric Focusing Method. Thesis Pharm. Dakar, 14.

[27] Mbodj, M., Ndoye, O., Diarra, M., Mbaye, B.N., Sow Touré, H., Diouf, L., Gassama Seck, S., Dhondt, J.L. and Farriaux, J.P. (2003) Neonatal Screening for Sickle Cell Anemia at Dakar CHU: Initial Assessment. Dakar Medical, 48, 202-205.

[28] Tshilolo, L., Aissi, L.M., Lukusa, D., Kinsiama, C., Wembonyama, S., Gulbis, B. and Vertongen, F. (2009) Neonatal Screening for Sickle Cell Anaemia in the Democratic Republic of the Congo: Experience from a Pioneer Project on 31204 Newborns. Journal of Clinical Pathology, 62, 35-38. https://doi.org/10.1136/jcp.2008.058958

[29] Odunvbun, M.E., Okolo, A.A. and Rahimy, C.M. (2008) Newborn Screening for 
Sickle Cell Disease in a Nigerian Hospital. Public Health, 122, 1111-1116. https://doi.org/10.1016/j.puhe.2008.01.008

[30] Kafando, E., Sawadogo, M., Cotton, F., Vertongen, F. and Gulbis, B. (2005) Neonatal Screening for Sickle Cell Disorders in Ouagadougou, Burkina Faso: A Pilot Study. Journal of Medical Screening, 12, 112-114. https://doi.org/10.1258/0969141054855300

[31] World Health Organization (2005) Sickle Cell Disease. EB117/34.

[32] Moreno, J.L. and Baribwira, C. (1994) Epidemiology of Sickle Cell Anemia in the Neonatal Period in Bujumbura (Burundi). Annals of Pediatrics, 41, 215-218.

[33] Serjeant, G.R. and Ndugwa, C.M. (2003) Sickle Cell Disease in Uganda: A Time for Action. East African Medical Journal, 80, 384-387. https://doi.org/10.4314/eamj.v80i7.8724

[34] Tshilolo, L., Mukendi, R. and Girot, R. (1996) Sickle Cell Anemia in Southern Zaire. Arch Pediatrics, 3, 104-111. https://doi.org/10.1016/0929-693X(96)85059-7

[35] Grover, R., Shahidi, S., Fisher, B., Goldberg, D. and Wethers, D. (1983) Current Sickle Cell Screening Program for Newborns in New York City, 1979-1980. American Journal of Public Health, 73, 249-252. https://doi.org/10.2105/AJPH.73.3.249

[36] Gulbis, B., Tshilolo, L., Cotton, F., Lin, C. and Vertongen, F. (1999) Newborn Screening for Haemoglobinopathies: The Brussels Experience. Journal of Medical Screening, 6, 11-15. https://doi.org/10.1136/jms.6.1.11

[37] Adorno, E.V., Couto, D., De Moura Neto, J.P., Menezes, J.F., Rego, M., Galvao Dos Reis, M. and Gonasalves, M.S. (2005) Hemoglobinopathies in Newborn from Salvador, Bahia, Northeast Brazil. Cadernos de Saúde Pública, 21, 292-298. https://doi.org/10.1590/S0102-311X2005000100032 